\title{
Collaborative lifelong learning and professional transfer. Case study: ECO European Project
}

\section{Carmen Marta-Lazo, Divina Frau-Meigs \& Sara Osuna-Acedo}

To cite this article: Carmen Marta-Lazo, Divina Frau-Meigs \& Sara Osuna-Acedo (2018): Collaborative lifelong learning and professional transfer. Case study: ECO European Project, Interactive Learning Environments, DOI: 10.1080/10494820.2018.1451346

To link to this article: https://doi.org/10.1080/10494820.2018.1451346

曲 Published online: 20 Mar 2018.

Submit your article to this journal $\pi$

Џ Article views: 68

Q View related articles $\sqsubset$

View Crossmark data ¿ 


\title{
Collaborative lifelong learning and professional transfer. Case study: ECO European Project
}

\author{
Carmen Marta-Lazo $\mathbb{( 1}^{\mathrm{a}}$, Divina Frau-Meigs $\oplus^{\mathrm{b}}$ and Sara Osuna-Acedo ${ }^{\mathrm{c}}{ }^{\mathrm{c}}$ \\ ${ }^{\mathrm{a}}$ General and Hispanic Linguistics Department (Area of Journalism), University of Zaragoza, Zaragoza, Spain; \\ ${ }^{\mathrm{b}}$ Anglophone Wold, University Sorbonne Nouvelle, Paris, France; 'Didactics and School Organization Department, \\ National Distance Education, University of Madrid, Spain
}

\begin{abstract}
This research reviews the formative model of the sMOOCs (social MOOC) characterized by the interaction and the implication of the participants who, relying on collective intelligence, look for the co-creation of knowledge in every educational action. The fieldwork focuses on the analysis of the "Step by Step" sMOOC of ECO Project (the second and third editions), that aims at the training of e-teachers and the transfer of learning to the professional field. The research methodology is mixed, with quantitative and qualitative techniques: it uses a semi-structured questionnaire, in order to compare possible bivariate correlations between the different variables; it conducts a content analysis of the fragments of messages written by the participants in the forums of the course. One of the most significant conclusions is the high degree of satisfaction of the participants with regard to the value of the course for their professional life. This form of transfer of the learning process leads to the proposal of a new modality for MOOCs, the tMOOC as "transferMOOC".
\end{abstract}

\section{ARTICLE HISTORY}

Received 21 December 2017

Accepted 8 March 2018

\section{KEYWORDS}

sMOOC; tMOOC;

collaborative learning;

relational factor; professional

transfer; e-teachers

\section{Introduction}

The "s" in the sMOOCs of the ECO project is a two-fold denomination as it relates to the two adjectives "social" and "seamless" (Camarero-Cano \& Cantillo-Valero, 2016). These sMOOCs are "social" because they promote participation and social interactions in learning, and "seamless" because they are accessible from mobile devices, which brings ubiquity to such courses since they can be accessible in any place, at any time and on any device. Altinpulluk and Kesim (2016) consider it to be a post-MOOC variation, as they consider the SMOOC in ECO incorporate a major degree of interaction and social participation. The pedagogical framework is based on the notion that MOOCs should be designed to accommodate the specific context of open online education with its heterogeneity of learners' needs. Digital inclusion, ubiquitous learning and gamification can provide affordances for active participation that meet the learners' needs (Brouns et al., 2017, p. 315).

The main contribution of the sMOOCs takes root in "intercreativity" (Osuna-Acedo et al., 2017), a term coined in 1996 by Tim Berners - Reads, that brings together two concepts, interactivity and creativity. Intercreativity refers to the capacity of individuals to create original elements and to be more productive inside a virtual environment based on collaboration and participation (Waite, Mackness, Roberts, \& Lovegrove, 2013). 
In this light, sMOOCs promote active and collaborative learning not only on the pedagogical side, but also on the citizenship side as they engage participants to contribute in social and civic activities (Martínez-Pérez, 2016). This is conducive to real transfer of knowledge, as it fosters opportunities for personal, professional and collective development. The research of Traphagan, Traphagan, Neavel Dickens, \& Resta (2014), based on the participation of students in Wikipedia's collaborative environment, concludes that such participation helps the students in three main areas: to contribute to the co-creation of information on the Web, to be more critical with the information on the Web and to evaluate the use of resources on the Web. They have observed that the open online contents can prepare the students better for their university and professional careers. The sMOOCs can manage to create different forms of e-participation based on combined collaboration and reflection that serve

\footnotetext{
"to extract useful propositions that help to shape the processes of decision-making in the areas of management and public policy-making. These pioneering forms of participation, with groups of common interest, deep-rooted and well-connected globally, have come with MOOCs and are going to revolutionize our way of constructing Society (Torres Mancera \& Gago Saldaña, 2014, p. 16).
}

In the area of engagement, sMOOCs can also serve to construct new forms of managerial or academic productivity. For example, the sMOOC "Step by Step" that is the focus of this research is an example of how this type of course helps in the undertaking of new learning formulas. This course concretely trains participants to turn into e- teachers, so that they know all the tools, methods of learning, systems of peer-to-peer evaluation, etc. in order to create their own massive online course on the subject matter of their choice.

\section{Collaborative learning and professional transfer: the case of the sMOOC "Step by Step" in ECO project}

Collaborative learning (Arnold, Kumar, Thillosen, \& Ebner, 2014) takes its theoretical roots in constructivism (Vigotsky, 1979) and connectivism (Siemens, 2004), whereby students develop their own process of knowledge construction and transfer it to their close environment. It entails some mediation, some of which is provided by the guide who acts as a learning facilitator and by other peers, in a process of negotiation of practices. In this type of learning

motivation increases, since it generates strong feelings of belonging and cohesion, across the identification of common goals and shared attributions, that makes one feel "part of" the process, stimulating one's productivity and responsibility, which will affect directly on one's self-esteem and development (Calzadilla, 2002, p. 5).

Collaboration in the learning processes implies different levels of activity. It can start from the simple response or linear comments in a specific forum, continue with a constant exchange of ideas in a permanent dialectical process, follow up with shared elaborate works of different nature (synthesis, reflection, documentation ...) and conclude with joint co-creation and co-authorship, where all contribute to the group, try to solve problems and look for solutions. Collaboration implies a sense of constant help from one another, of development of "cybercultural competences" (Chan Núñez, 2015) and of contribution from the holistic richness that "collective intelligence" brings with itself (Lévy, 2004).

Creating is at the top of high order thinking, according to Bloom's taxonomy (1986), that goes beyond other levels of objectives: remembering, comprehending, applying, analysing, synthesizing and evaluating. In this sense, co-creation for pedgogical transformation in $\mathrm{TMOOC}$ (transferMOOC), as seen by Osuna-Acedo, Marta-Lazo, \& Frau-Meigs (2018) fosters the shared quality of knowledge development while collaboration multiplies its effects.

The configuration of new collaborative work strategies in MOOCs, complemented with contributions from social networks and other tools (Veletsianos, Collier, \& Schneider, 2015) allow specific interactions that increase motivation performance (Castaño-Garrido, Maiz-Olazabalaga, \& GarayRuiz, 2015; Sosa, López, \& Díaz, 2014). In the best of cases, such interactions lead to the creation of 
"communities of learning” (Cruz-Benito, Borrás-Gené, García-Peñalvo, Fidalgo Blanco, \& Therón, 2016).

\subsection{The sMOOC "Step by Step" in ECO project}

The main objective of the sMOOC "Step by Step" was precisely to serve as preparation to turn the participants into e-teachers, as they learnt everything necessary to create their own sMOOC. With this aim in mind, the specific objectives of the project were:

- To identify the main trends of virtual training

- To recognize the possibilities that sMOOCs offer as resources for teacher training in different areas, levels and contexts

- To develop skills for the creation of a sMOOC, step by step, in response to such questions as: Why? How? With What management? What use of technologies? How accessible? With what diffusion? And with what evaluation and use of data?

- To develop skills for the diffusion of sMOOCs

- To use technological resources for the making of sMOOCs both individually and collaboratively (ecolearning, 2015; Osuna-Acedo \& Gil-Quintana, 2017; Frau-Meigs \& Bossu, 2017).

The goal of this project is to manage to be a model in the creation and implementation of sMOOCs on a large scale, introducing mobile devices in the m-learning. The sMOOC "Step by Step" is given in six languages and is part of the European Project ECO (E-learning, Communication and Open-data), placed inside the Competitiveness and Innovation Framework Programme (CIP-ICT-PSP.2013). This sMOOC relies on the participation of ten European institutions for higher education in six different countries and is coordinated by the Sorbonne Nouvelle University in France and the National University for Distance Education (UNED) in Spain.

This $S M O O C$ relies on a pedagogical design coherent with the requirements of the digital era as they expect participants to be co-responsible in their own learning. At the end of the sMOOC, the participants must have dealt with the following questions: Why do a sMOOC? How is a sMOOC built? How is a sMOOC designed? How to make a sMOOC accessible and successful? How is a sMOOC assessed and its data used? As such the sMOOC "Step by Step" is a "metaMOOC" (OsunaAcedo \& Gil-Quintana, 2017) since it appears as "an invitation to think about the role that massive online open training, especially sMOOCs, play in the 21 st century, in any learning process" (ecolearning, 2015; Gil-Quintana, 2016; Mañero-Contreras, 2016).

This formative offer appears as an opportunity to create communities of professionals that can use the same strategies of open online training for their professional development. It takes into account the influence of usability and the technological self-efficiency in the acceptance of technology by participants (Holden \& Rada, 2011). The philosophy for training as well as the contents of the designed courses are explicitly thought through to bridge the digital gap and to look for increasingly inclusive technological and educational strategies (Calvo, Rodríguez, \& Fernández, 2016, p. 301).

\section{Method}

The analysis is based on the results obtained in the sMOOC "Step by Step" showing that the participants want to learn and to transfer their knowledge as e-teachers with critical mind and skills for creating their own SMOOC. The purpose of this research is to present the perception of the two hundred ninety two students who attended the sMOOC "Step by Step", in its first and second edition, bearing in mind that it deals with educational and communicative practices based on collaborative learning and transfer of knowledge to real life professional practice.

The results describe, analyse and clarify the observed reality. The information is 
arranged, summarized and classified in order to have a more precise and joint vision of the observations, thus trying to discover possible relations between the various data, seeing which ones take similar values, which ones differ greatly from the rest, emphasizing facts of possible interest, etc. (García Pérez, 2011, p. 27).

This analysis rests on two research questions and three attendant hypotheses that have guided the construction of the information obtained using quantitative and qualitative techniques.

\subsection{Research questions and hypotheses}

The aim of this research consists in gathering the degree of satisfaction of the participants of the sMOOC "Step by Step", who are teachers in their vast majority. Additionally, the purpose is to verify if what they learn is directly injected in their professional field.

Accordingly, two research questions guide the analysis carried out:

Q1: What is it the satisfaction of the participants in relation to their initial expectations and the level of learning acquired?

Q2: What is the satisfaction of the participants in relation to the application of what they learned directly in their daily professional life?

The answers of the participants try to verify three hypotheses:

$\mathrm{H} 1$ : The application of collaborative learning has special value for the participant in the transfer of knowledge acquired towards their professional life.

$\mathrm{H}$ 2. The satisfaction of the participants in relation to their expectations depends on the design of collaborative practices inside the sMOOC "Step by Step".

$\mathrm{H} 3$. The satisfaction of the participants in relation to the level of learning obtained is associated with the design of collaborative practices inside the sMOOC "Step by Step".

\subsection{Data collection}

The data collection includes quantitative and qualitative information. Quantitative data were obtained from the answers of the participants to the online satisfaction questionnaire distributed at the end of the course, that allows for "to study a phenomenon in standardized form, restraining as much as possible the interference of the more or less conscious biases of the researcher" (Hueso \& Cascant, 2012, p. 3).

The semi-structured questionnaire with multiple answers was elaborated so that every participant could answer in a voluntary and anonymous manner. The questionnaire was constructed using LimeSurvey software, and the data were treated using SPSS. This tool ensured that the presence of the researcher did not influence the answers of the participants, which allows the standardization of the answers provided in the sample (Corbetta, 2007). The questionnaire is composed of 30 questions based on Likert's scale with mostly dichotomous answers, validated by experts before its administration. As for the qualitative data, they were collected via a selection of contents that the participants wrote in the forums all along the course. Once the different fragments of contents were gathered, they were cataloged and categorized via the Atlas.TI. This made it possible to analyse their meaning and as well as their derived conceptual fields.

The answers to the questionnaires and the categorization of contents both aimed at identifying the level of satisfaction of the participants in relation to their expectations, their level of learning and their capacity to transfer it to their professional field. All this was carried out following the connectivist approach to learning (Siemens, 2004; Wenqiang, 2012), with some elements of constructivism as the design of the SMOOC accommodated eminently collaborative activities facilitated by the pedagogical team.

\subsection{Analysis of results}

The triangulation of qualitative and quantitative techniques "generates a feeling of solidity" when the convergence of results produced by different methods or techniques of research is confirmed 
(Callejo \& Viedma, 2010). With the quantitative techniques, numerical values have been assigned to the answers of the participants in order to study the possible relations between the different variables.

The qualitative technique is a sort of ethnographic study applied to massive open online education to detect the social relations and interactions that take place in the forums of the sMOOC "Step by Step".

The total sample of this study amounts to 292 participants who voluntarily answered the questionnaire of the end of the course, with ages ranging between 19 and 73 years. The sample is composed of $52.1 \%$ of women and 47.9 remaining \% of men, a rather balanced sample distribution. As for profiles, Table 1 shows that the dominant qualification in the sample is Doctorate $(50.3 \%)$, followed by Bachelor's degree (15.1\%), Associate degree (occupational/technical/vocational program) (12.3\%) and Associate degree (academic program) (9.6\%).

Table 2 presents the most representative areas of employment in the sample, with only two majority groups of occupations: $54.1 \%$ of the participants devote themselves to teaching and education, and the rest to areas not in education. In the latter group, the most significant percentage (8.6\%) belongs to Computer science, mathematics, or information technology.

\subsubsection{Analysis of the satisfaction with the learning acquired in the sMOOC "Step by Step" and the expectations fulfilled in relation to the value of introducing collaborative tasks for the transfer of knowledge in professional life}

This hypothesis has been tested by analysing the socio-educational of the participants to determine if some characteristics exists that could be related to the transfer of knowledge acquired in the course in relation to professional activity, since more than half the sample is composed of employed teachers. Table 3 presents the $p$-values of the chi-square tests for the independence between the socio-educational characteristics (X1, X4 and X18) and the satisfaction of initial expectations, the content learned and its professional application (X64, X63 and X62).

There is a clear dependence observed between the satisfaction of the participants in relation to their expectations, the level of learning obtained and the application of contents to the professional daily life in the $S M O O C$ with the variables X1 (age), X4 (academic qualification) and X18 (design of collaborative tasks).

Table 1. Academic qualification distribution in the sMOOC.

\begin{tabular}{lrr}
\hline \multicolumn{2}{c}{ X4_Academic_qualifications } & \\
\hline Associate degree - academic program & Frequency & Percentage \\
Associate degree - occupational/technical/vocational program & 28 & 9.6 \\
Bachelor's degree (e.g. BA, AB, BS) & 36 & 12.3 \\
Doctorate degree (e.g. PhD, EdD) & 44 & 15.1 \\
Master's degree (e.g. MA, MS, MEng, MEd, MSW, MBA) & 147 & 50.3 \\
Professional school degree (e.g. MD, DDS, DVM, LLB, JD) & 7 & 2.4 \\
Some college but no degree & 10 & 3.4 \\
Secondary education & 18 & 6.2 \\
Some primary or elementary school & 1 & 0.3 \\
Total & 1 & 0.3 \\
\hline
\end{tabular}

Table 2. Area of employment distribution in the sMOOC.

\begin{tabular}{lcr}
\hline & X6_Area_of_employment__ & Percentage \\
\hline Employed in Educational areas & Frequency & 56.5 \\
Employee in non-educational areas & 165 & 43.5 \\
Total & 127 & 100.0 \\
\hline
\end{tabular}


Table 3. $P$-values of chi-square tests for the independence of Variables X1 (Age) by X4 (Academic Qualifications) and X 18 (Design of Collaborative Tasks).

\begin{tabular}{lccc}
\hline & $\begin{array}{c}\text { X64 } \\
\text { Did_MOOC_meetyour_ } \\
\text { expectations }\end{array}$ & $\begin{array}{c}\text { X63 } \\
\text { How_much_didyou_ } \\
\text { learn_in_MOOC }\end{array}$ & $\begin{array}{c}\text { X62 Applications_of } \\
\text { MOOCcontent_in_- } \\
\text { daily_professional_life }\end{array}$ \\
\hline X1: Age $(n=268)$ & $\mathbf{0 . 0 0 0 ^ { * }}$ & $\mathbf{0 . 0 0 3 ^ { * }}$ & $\mathbf{0 . 0 0 1 *}^{*}$ \\
X4: Academic_qualifications $(n=292)$ & $\mathbf{0 . 0 0 0 ^ { * }}$ & $\mathbf{0 . 0 0 0 ^ { * }}$ & $\mathbf{0 . 0 0 0 *}^{*}$ \\
X18: Design_collaborative_tasks $(n=292)$ & $\mathbf{0 . 0 0 0 *}^{*}$ & $\mathbf{0 . 0 0 0}^{*}$ & $\mathbf{0 . 0 0 0}^{*}$ \\
\hline
\end{tabular}

*The relationship is significant at 0.01 .

Table 4 provides the Kendall and Spearman correlation coefficients between variables X1 (Age), X64 (expectations), X63 (content learned) and X62 (application in professional life). The results show a negative correlation between age and the expectations fulfilled in the sMOOC: significantly, age influences negatively the expectations of the participants, which means that the older the participant, the less his or her satisfaction with the expectations in attending sMOOC. On the contrary, the results show a very positive correlation between the fulfilled expectations, the level of learning reached and the application of the content in daily professional life. Table 4 also shows that there is no correlation between variable X4 (Academic qualifications) and the rest of the variables.

Finally Table 5 provides the Kendall and Spearman correlation coefficients between variables X18, $\mathrm{X} 64, \mathrm{X} 63$ and $\mathrm{X} 62$. The results show a very positive correlation between four variables: significantly, the design of collaborative tasks in the SMOOC influences positively the fulfilled expectations of the participants, the level of learning reached and the application that their professional daily life, which means that the more collaborative activities are used, the more satisfaction there is with the three dimensions under study.

\subsubsection{Content analysis of the content expressed by participants in the forums of the sMOOC "Step by Step"}

Among all the messages written in the forums of the sMOOC "Step by Step" by the participants, 1.100 fragments were selected that gather significant comments. Among them, 649 fragments are related to the variables X18 (Design collaborative tasks) and X62 (Applications of content in daily professional life). So more than half of the messages focus on commenting on these two variables.

The qualitative analysis of these units of meaning aims at identifying the beliefs and values of the participants concerning the sMOOC "Step by Step" and their own process of interaction. According to Piñuel's definition $(2002$, p. 2) "content analysis is defined as the set of interpretive procedures of communicative products (messages, texts or speeches) that come from singular processes of communication previously registered".

Table 6 presents the categories associated with variables X18 and X62 in the messages written by the participants.

As for the design of collaborative tasks, the biggest percentage of the messages is about facilitation (FactCol, 20\%). It means that the participants are voluntarily implicated in facilitating the collaborative tasks. The messages that come next in importance relate to reciprocal gratefulness for facilitation (ST-AFActCol, 10.9\%). The other two categories, about spontaneous collaboration (STApColCocre, 5.45\%) and taste for collaboration (ST-GactCol, 2.72\%), even though they are low in percentages, are very significant, since they show, respectively, that a qualitative jump really takes place towards co-creation and co-authorship and that there is a manifest need for collaborative activities.

When considering the five resulting categories in the variable about the application of the contents of the sMOOC in the participants' professional life, the importance that their profession takes as part of their identity appears clearly. When the participants want to present themselves to the group, they mention their name, origin and profession, which results in the category STPrPron obtaining a high percentage (11.72\%). The three other categories, ST-ApMOOC (2.54\%), STUETeac (2.54\%) and ST-CaProMOOC (2.27\%) present similar percentages, which points to three 
Table 4. Kendall and Spearman correlation coefficients between variables X1 (Age) and X64 (expectations), X63 (content learned) and X62 (Applications in professional life).

\begin{tabular}{|c|c|c|c|c|c|c|c|}
\hline \multicolumn{8}{|c|}{ Correlations } \\
\hline & & & $\begin{array}{c}\mathrm{X} 1 \\
\text { Age }\end{array}$ & $\begin{array}{l}\text { X4_Academic_- } \\
\text { qualifications }\end{array}$ & $\begin{array}{l}\text { X64 Did_MOOC_ } \\
\text { meetyour_expectations }\end{array}$ & $\begin{array}{c}\text { X63 } \\
\text { How_much_did_- } \\
\text { you_learn inMOOC }\end{array}$ & $\begin{array}{l}\text { X62 Applications__ } \\
\text { MO0C_content_in_daily_ } \\
\text { professional_life }\end{array}$ \\
\hline \multirow{15}{*}{$\begin{array}{r}\text { Tau_b de } \\
\text { Kendall }\end{array}$} & \multirow[t]{3}{*}{ X1_Age } & Correlation coefficient & 1.000 & -.075 & $-.093^{*}$ & -.091 & -.038 \\
\hline & & Sig. (bilateral) & . & .107 & .050 & .057 & .420 \\
\hline & & $N$ & 268 & 268 & 268 & 268 & 268 \\
\hline & \multirow[t]{3}{*}{ X4_Academic_qualifications } & Correlation coefficient & -.075 & 1.000 & .001 & .012 & .035 \\
\hline & & Sig. (bilateral) & .107 & (1) & .980 & .803 & .480 \\
\hline & & $N$ & 268 & 292 & 292 & 292 & 292 \\
\hline & \multirow[t]{3}{*}{ X64_Did_MOOC_meet_your_expectations } & Correlation coefficient & $-.093^{*}$ & .001 & 1.000 & $.715^{* *}$ & $.562^{* *}$ \\
\hline & & Sig. (bilateral) & .050 & .980 & . & .000 & .000 \\
\hline & & $N$ & 268 & 292 & 292 & 292 & 292 \\
\hline & \multirow[t]{3}{*}{ X63_How_much_did_you_learn_in_MOOC } & Correlation coefficient & -.091 & .012 & $.715^{* *}$ & 1.000 & $.598^{* *}$ \\
\hline & & Sig. (bilateral) & .057 & .803 & .000 & & .000 \\
\hline & & $N$ & 268 & 292 & 292 & 292 & 292 \\
\hline & \multirow{3}{*}{$\begin{array}{l}\text { X62_Applications_MOOC_content_in_daily_ } \\
\text { professional_life }\end{array}$} & Correlation coefficient & -.038 & .035 & $.562^{* *}$ & $.598^{* *}$ & 1.000 \\
\hline & & Sig. (bilateral) & .420 & .480 & .000 & .000 & . \\
\hline & & $N$ & 268 & 292 & 292 & 292 & 292 \\
\hline & \multirow[t]{3}{*}{ X1_Age } & Correlation coefficient & 1.000 & -.095 & -.119 & -.119 & -.048 \\
\hline \multirow[t]{14}{*}{ Rho de } & & Spearman & & 121 & 052 & & \\
\hline & & Sig. (bilateral) & . & .121 & .052 & .052 & .432 \\
\hline & $N$ & 268 & 268 & 268 & 268 & 268 & \\
\hline & \multirow{3}{*}{ X4_Academic_qualifications } & Correlation coefficient & -.095 & 1.000 & .002 & .016 & .042 \\
\hline & & Sig. (bilateral) & .121 & & .969 & .790 & .480 \\
\hline & & $N$ & 268 & 292 & 292 & 292 & 292 \\
\hline & \multirow[t]{3}{*}{ X64_Did_MOOC_meet_your_expectations } & Correlation coefficient & -.119 & .002 & 1.000 & $.760^{* *}$ & $.621^{* *}$ \\
\hline & & Sig. (bilateral) & .052 & .969 & . & .000 & .000 \\
\hline & & $N$ & 268 & 292 & 292 & 292 & 292 \\
\hline & \multirow[t]{3}{*}{ X63_How_much_did_you_learn_in_MOOC } & Correlation coefficient & -.119 & .016 & $.760^{* *}$ & 1.000 & $.651^{* *}$ \\
\hline & & Sig. (bilateral) & .052 & .790 & .000 & . & .000 \\
\hline & & $N$ & 268 & 292 & 292 & 292 & 292 \\
\hline & \multirow{3}{*}{$\begin{array}{l}\text { X62_Applications_MOOC_content_in_ } \\
\text { daily_professional_life }\end{array}$} & Correlation coefficient & -.048 & .042 & $.621^{* *}$ & $.651^{* *}$ & 1.000 \\
\hline & & Sig. (bilateral) & .432 & .480 & .000 & .000 & . \\
\hline$N$ & & 268 & 292 & 292 & 292 & 292 & \\
\hline
\end{tabular}

*The relationship is significant at 0.05 (bilateral).

**The relationship is significant at 0.01 (bilateral). 
Table 5. Kendall and Spearman correlation coefficients between X18 (Design of collaborative tasks) and X64 (expectations), X63 (content learned) and X62 (Applications in professional life).

\begin{tabular}{|c|c|c|c|c|c|c|}
\hline \multicolumn{7}{|c|}{ Correlations } \\
\hline & & & $\begin{array}{c}\text { X18 } \\
\text { Design_collaborative_tasks }\end{array}$ & $\begin{array}{c}\text { X64 } \\
\text { Did_MOOC_meet_- } \\
\text { your_expectations }\end{array}$ & $\begin{array}{c}\text { X63 } \\
\text { How_much_did_ } \\
\text { you_learn in_MOOC }\end{array}$ & $\begin{array}{c}\text { X62 } \\
\text { ApplicationMOOC_content__ } \\
\text { in_daily_professional_life }\end{array}$ \\
\hline \multirow[t]{12}{*}{ Tau_b de Kendall } & \multirow[t]{3}{*}{ X18_Design_collaborative_tasks } & Correlation Coefficient & 1.000 & $.438^{* *}$ & $.396^{* *}$ & $.318^{* *}$ \\
\hline & & Sig. (bilateral) & & .000 & .000 & .000 \\
\hline & & $N$ & 292 & 292 & 292 & 292 \\
\hline & \multirow[t]{3}{*}{ X64_Did_MO0C_meet_your_expectations } & Correlation coefficient & $.438^{* *}$ & 1.000 & $.715^{* *}$ & $.562^{* *}$ \\
\hline & & Sig. (bilateral) & .000 & & .000 & .000 \\
\hline & & $N$ & 292 & 292 & 292 & 292 \\
\hline & \multirow[t]{3}{*}{ X63_How_much_did_you_learn_in_MOOC } & Correlation coefficient & $.396^{* *}$ & $.715^{* *}$ & 1.000 & $.598^{* *}$ \\
\hline & & Sig. (bilateral) & .000 & .000 & . & .000 \\
\hline & & $N$ & 292 & 292 & 292 & 292 \\
\hline & \multirow{3}{*}{$\begin{array}{l}\text { X62_Applications_MOOC_content_in_ } \\
\text { daily_professional_life }\end{array}$} & Correlation coefficient & $.318^{* *}$ & $.562^{* *}$ & $.598^{* *}$ & 1.000 \\
\hline & & Sig. (bilateral) & .000 & .000 & .000 & . \\
\hline & & $N$ & 292 & 292 & 292 & 292 \\
\hline \multirow[t]{12}{*}{ Rho de Spearman } & \multirow[t]{3}{*}{ X18_Design_collaborative_tasks } & Correlation coefficient & 1.000 & $.500^{* *}$ & $.453^{* *}$ & $.364^{* *}$ \\
\hline & & Sig. (bilateral) & & .000 & .000 & .000 \\
\hline & & $N$ & 292 & 292 & 292 & 292 \\
\hline & \multirow[t]{3}{*}{ X64_Did_MOOC_meet_your_expectations } & Correlation coefficient & $.500^{* *}$ & 1.000 & $.760^{* *}$ & $.621^{* *}$ \\
\hline & & Sig. (bilateral) & .000 & . & .000 & .000 \\
\hline & & $N$ & 292 & 292 & 292 & 292 \\
\hline & \multirow[t]{3}{*}{ X63_How_much_did_you_learn_in_MOOC } & Correlation coefficient & $.453^{* *}$ & $.760^{* *}$ & 1.000 & $.651^{* *}$ \\
\hline & & Sig. (bilateral) & .000 & .000 & . & .000 \\
\hline & & $N$ & 292 & 292 & 292 & 292 \\
\hline & \multirow{3}{*}{$\begin{array}{l}\text { X62_Applications_MOOC_content_in_ } \\
\text { daily_professional_life }\end{array}$} & Correlation coefficient & $.364^{* *}$ & $.621^{* *}$ & $.651^{* *}$ & 1.000 \\
\hline & & Sig. (bilateral) & .000 & .000 & .000 & . \\
\hline & & $N$ & 292 & 292 & 292 & 292 \\
\hline
\end{tabular}

**The relationship is significant at 0.01 (bilateral). 
Table 6. Categories of participants' content in forums about X18 and X62 variables.

\begin{tabular}{|c|c|c|c|c|}
\hline & Code & Category & Intentionality & Frequency \\
\hline $\mathrm{X} 18$ & ST - GActCol & Taste for collaborative activities & Manifested need for collaborative activities & $2.72 \%$ \\
\hline \multirow[t]{3}{*}{ Design_collaborative_tasks } & ST - ApColCocre & Spontaneous collaborative help and co-creation & Animation of collaborative tasks to reach co-creation & $5.45 \%$ \\
\hline & ST - FActCol & Facilitation of collaborative activities & Search for links and resources for collaborative learning & $20 \%$ \\
\hline & ST - AFActCol & Gratefulness for facilitation of collaborative activities & Gratefulness for links and resources & $10.9 \%$ \\
\hline \multicolumn{5}{|l|}{ TOTAL: 39.07\% } \\
\hline \multirow{5}{*}{$\begin{array}{l}\text { X62 Applications_MOOC_content_in_ } \\
\text { daily_professional_life }\end{array}$} & ST - ApMOOC & Support to profesional actualization with MOOC & Sense of social importance to generate more MOOCs & $2.54 \%$ \\
\hline & ST - CaProMOOC & $\begin{array}{l}\text { Recognition for profesional accreditation with } \\
\text { MOOC }\end{array}$ & Confirmation of knowledge transfer to professional life & $2.27 \%$ \\
\hline & ST - IdPro & Professional identification & Identification between similar professions & $0.54 \%$ \\
\hline & ST - PrPro & Presentation of profession & Presentation of name and profession in first message & $\begin{array}{l}\text { 8.18\% Teachers } \\
3.54 \% \text { Not teachers }\end{array}$ \\
\hline & ST - UETeac & Proposal of e-teacher project & Empathy between participants to create an e-teacher MOOC & $2.54 \%$ \\
\hline \multicolumn{5}{|l|}{ TOTAL: $19.61 \%$} \\
\hline
\end{tabular}


aspects: the social importance of continuing to produce MOOCs, the need to join forces as e- teachers to design MOOCs together and the recognition of the professional capacitation of MOOCs for training.

\section{Discussion}

Q1: What is it the satisfaction of the participants in relation to their initial expectations and the level of learning acquired?

In the quantitative analysis of this study, the results show that age influences the expectations, but not the level of learning of the students in the sMOOC "Step by Step". The academic level does not influence any of the variables of this study. In the answers of satisfaction of the participants, there is a very positive correlation between the fulfilled expectations and the level of learning.

Fostering inter-creative activities that facilitate the co-creation and the co-authorship increases the implication of the participants. Promoting the empowerment of the participants leads them to feel co-responsible for their learning and their decision-making during the course. The high levels of satisfaction exhibited in the participants' questionnaire relating to the fulfillment of their expectations and the level of learning reached, are reaffirmed by the messages on the forums where the participants exchange with their peers and offer their voluntarily work for the construction of knowledge (such as providing synthesis, collective reflections or documented contributions to the topics treated in the course.

There are explicit manifestations about the support that they give to collaboration and to the design of collaborative tasks inside the process of education and learning. There is an evidence of a natural form of training in a "community of learning" where the role of the professorship is that of mediator of the process, as was initially aimed in the connectivist and constructivist design of the sMOOC "Step by Step". Such a process confirms the relevance of TRICs (Technologies of Relation, Information and Communication) as described by Marta-Lazo, Hergueta-Covacho, \& Gabelas-Barroso (2016) as the basis for digital humanism, beyond mere technological determinism. Learning with TRICs aims at a more inclusive and participatory society, with all the benefits that critical reading and creation offer in terms of social transformation. Hence, the importance of promoting "the Relational Factor in horizontal, collaborative and ethical learning" in sMOOCs (Marta-Lazo, MarfilCarmona \& Hergueta-Covacho, 2016, p. 316).

Q2: What is the satisfaction of the participants in relation to the application of what they learned directly in their daily professional life?

Neither age nor academic qualification exert an influence on the application of the content learned to the professional life. Nevertheless, there is a positive correlation between the design of the collaborative tasks and the application of the contents to the professional life. So there is "transfer of learning" that posits a new model that represents a new orientation of the $\mathrm{SMOOC}$ as it evolves towards a tMOOC or transfer MOOC. In this respect, "the open methodology of the SMOOC satisfies the expectations that the participants invest in such course since they offer a great opportunity to share information, to communicate, to experience new ways of learning and of collaborating" (Camarero-Cano \& Cantillo-Valero, 2016, p. 33).

The level of satisfaction of the participants in the forum in relation to the professional applicability of the content they learnt to their daily labor activity is corroborated by the fact that half of the messages in the forums center on comments about the interest for the design of collaborative activities and professional transformation. Their interest in facilitating voluntary collaboration $(20 \%$ of the messages) and their gratefulness for the collaboration (10.9\%) must not be understood only as an act of politeness, since such messages then lead to a posterior action, that of requesting a space in the platform to become e-teachers of their own tMOOC. Three important aspects in the messages of the forums are revealing: the social importance of generating MOOCs, the need to join forces as eteachers and the recognition that MOOCs augment professional capacity-building. 


\section{Conclusions}

One of the main disadvantages that hinder MOOCs today is their high rate of attrition, generally estimated at an average of $95 \%$, according to the literature search (Yousef, Chatti, Wosnitza, \& Schroeder, 2015 , p. 86). Some pedagogic problems related to feedback and evaluation are also often taken in consideration (Hill, 2013). However, sMOOCs that facilitate the transfer of knowledge and present prospective contributions towards the professional field that go beyond the scope of the course, keep the participants hooked and interactive to a major degree, motivating them to finish the course to reach a clear goal, that of creating their own sMOOC as in the case of the "Step by Step". The sample shows that participants who completed the course have positively overcome the general rate of attrition of MOOCs.

However, if the 90-9-1 Rule of Nielsen (2006) is applied, it appears that Nielsen's 1\% (critical participants) corresponds in the "Step by Step" to participants who have completed the SMOOC, acting critically during the sessions, co-constructing their knowledge with others and participating of the coauthorship of all the generated materials. They can be considered as intermediate leaders, in their relation to the professorship facilitation. Nielsen's $9 \%$ (participants who tag along) corresponds to participants who have taken part moved by the participation of the $1 \%$. Finally, Nielsen's $90 \%$ (mere observers) corresponds to the remaining group that has not had an implicated participation. Beyond such rule, Siemens, Downes, and Cormier (2012) suggestion to use as criterion the new role of the participants in MOOCs is advisable:

If the MOOC seems to be too complicated, do not read it. If it seems boring, go to the next one. The results of the learning process will be different for every person.

This research suggests a modification in the MOOC typology, taking into account the evolution from sMOOC to tMOOC. TMOOC has a twofold objective in relation to learning transfer: towards empowerment and towards social transformation, as they motivate participants to engage in changes in their daily lives, as professionals and eventually as citizens. In this respect, the "Step by Step" extend the original modality noticed by some researchers (Cabero Almenara, Llorente Cejudo, \& Vázquez Martínez, 2014; Vázquez, López, \& Sarasola, 2013) for whom the "t" in tMOOC only related to the resolution of tasks and activities by the participants. In this extended modality, the "t" represents both "transfer" and "transformation", that is the transformative capacity of the "relational factor" for inclusiveness and participation.

As for future research lines, we propose working on a more social, transforming approach to tMOOC-based learning analysing, for instance, the importance of multicultural coexistence processes for the citizenship commitment. For that matter, tMOOCs should continue to be researched from an active and collaborative learning promotion perspective, not only on its pedagogical side, but also as a stake for social empowerment.

\section{Disclosure statement}

No potential conflict of interest was reported by the authors.

\section{Funding}

This work was supported by the Seventh Framework Programme: European Project Elearning, Communication \& OpenData (ECO): European Commission [Grant Number: 621127].

\section{Notes on contributors}

Dr. Carmen Marta Lazo is a Journalism Senior Lecturer in University of Zaragoza. She is a main Researcher in Digital Communication and Information Research Group (GICID) at the University of Zaragoza, recognized by regional Government of Aragón, in the area of Social Science with grants by the European Social Fund. She is Co-editor and secretary of the editorial board of Mediterranean Journal of Communication. She has organized numerous scientific forums related to her 
research lines, based on Media Education, Digital Competence and screen consumptions and interactions. She has participated as a main researcher of the partner of the University of Zaragoza in the ECO Project.

Dr. Divina Frau Meigs is a university professor at Sorbonne Nouvelle University. Her main research themes deal with media and information literacy, e-learning, internet governance and cultural diversity. She has published numerous articles and more than 20 books in this field, the last one being Public Policies in Media and Information Literacy in Europe: cross-country comparisons (Routledge 2017). She co-ordinated the implementation of the EC-Funded Project ECO and she was responsible for ANR Project TRANSLIT and Erasmus + Project ECFOLI. She holds the UNESCO Chair "Savoir Devenir in durable digital development: mastering information cultures".

Dr. Sara Osuna is a Professor of Communication and Education, teaching on Pedagogy and Social Education in undergraduate programs. Her expertize mainly focuses on digital technologies, Communication Models and eLearning. Her main lines of research are MOOCs, Media convergence, Digital scenarios, Disability, eLearning and Social Media. She has coordinated during three year-long (2014-17), EC-funded project ECO: "E-learning, Communication and Opendata: Mobile, Massive and Ubiquitous Learning".

\section{ORCID}

Carmen Marta-Lazo (D) http://orcid.org/0000-0002-0004-1094

Divina Frau-Meigs (D) http://orcid.org/0000-0002-0369-4226

Sara Osuna-Acedo (D) http://orcid.org/0000-0002-5454-6215

\section{References}

Altinpulluk, H., \& Kesim, M. (2016). The evolution of MOOCs and a clarification of terminology through literature review. Re-Imaging Learning Environments. Proceedings of the European Distance and E-Learning Network, 2016 Annual Conference, At Budapest, Hungary, 220-231. Retrieved from https://goo.gl/wMjdf8

Arnold, P., Kumar, S., Thillosen, A., \& Ebner, M. (2014). Offering cMOOCs collaboratively: The COER13 experience from the convenors' perspective. eLearning Papers, 37, 63-68. Retrieved from http://goo.gl/Kvm6BG

Berners-Lee, T. (1996). WWW: Pasado, presente y futuro. Computadora, 29(10), 69-77. Retrieved from https://goo.gl/ ekJqE6

Bloom, B. S. (1986). What we are learning about teaching and learning: A summary of recent research. Principal, 66(2), 6-10.

Brouns, F., Teixeira, A., Morgado, L., Fano, S., Fueyo, A., \& Jansen, J. (2017). Designing massive open online learning processes: The sMOOC pedagogical framework. In M. Jemni, M. Kinshuk, \& M. Khribi (Eds.), Open education: From OERs to MOOCs (pp. 315-336). Berlin, Heidelberg: Springer. doi:10.1007/978-3-662-52925-6_16

Cabero Almenara, J., Llorente Cejudo, M. C., \& Vázquez Martínez, A. I. (2014). Las tipologías de MOOC. Su diseño e implicaciones educativas. Profesorado. Revista de currículum y formación del profesorado, 18(1), 13-26. Retrieved from https://goo.gl/XkTSpB

Callejo, J., \& Viedma, A. (2010). Proyectos y estrategias de investigación social: la perspectiva de la intervención. Madrid: McGraw Hill.

Calvo, M. A., Rodríguez, C., \& Fernández, E. M. (2016). ¿Cómo son los MOOC sobre educación? Un análisis de cursos de temática pedagógica que se ofertan en castellano. Digital Education Review, 29, 298-311. Retrieved from https://goo. gl/1aSZRE

Calzadilla, M. E. (2002). Aprendizaje colaborativo y tecnologías de la información y la comunicación. Revista Iberoamericana de educación. Retrieved from https://goo.gl/GUQdLM

Camarero-Cano, L., \& Cantillo-Valero, C. (2016). La evaluación de los aprendizajes en los sMOOC. Estudio de caso en el Proyecto Europeo ECO. Revista Mediterránea de Comunicación / Mediterranean Journal of Communication, 7(2), 2135. doi:10.14198/MEDCOM2016.7.2.2

Castaño-Garrido, C., Maiz-Olazabalaga, I., \& Garay-Ruiz, U. (2015). Design, motivation and performance in a cooperative MOOC course. Comunicar, 22(44), 19-26. doi:10.3916/C44-2015-02

Chan Núñez, M. E. (2015). Comunidades y redes académicas en los ecosistemas de conocimiento. Archivos de Ciencias de la Educación, 9, 1-16. Retrieved from https://goo.gl/3TJQcS

Corbetta, P. (2007). Metodología y técnicas de investigación social. Edición revisada. Madrid: McGraw-Hill/Interamericana de España.

Cruz-Benito, J., Borrás-Gené, O., García-Peñalvo, F. J., Fidalgo Blanco, Á, \& Therón, R. (2016). Comunidades de Aprendizaje en Redes Sociales y su Relación con los MOOC. VAEP-RITA, 4(2), 87-99. Retrieved from https://goo.gl/f1NzhM

Ecolearning. (2015). sMOOC Paso a Paso. European Project E-learning, Communication and Open-data (ECO). Retrieved from https://goo.gl/FZEJGX

Frau-Meigs, D., \& Bossu, A. (2017). Towards e-presence at distance as a way to reach and share e-quality: The case of the ECO sMOOCs. In C. Delgado Kloos, P. Jermann, M. Pérez-Sanagustín, D. Seaton, \& S. White (Eds.), Digital Education: Out to the World and Back to the Campus. EMOOCs 2017 (pp. 38-47). Heidelberg: Springer. doi:10.1007/978-3-319-59044-8_5 
García Pérez, A. (2011). Estadística aplicada: Conceptos básicos. Madrid: UNED.

Gil-Quintana, J. (2016). La nueva realidad SMOOC, una ventana abierta a la educomunicación. Revista Mediterránea de Comunicación, 7(2), 59-68. doi:10.1498/MEDCOM2016.7.2.5

Hill, P. (2013). Emerging student patterns in MOOCs: A (revised) graphical view -. e-Literate. Posted on March 10. Retrieved from https://goo.gl/YYzmmQ

Holden, H., \& Rada, R. (2011). Understanding the influence of perceived usability and technology self-efficacy on teachers' technology acceptance. Interactive Learning Environments, 43(4), 343-367. doi:10.1080/15391523.2011.10782576

Hueso, A., \& Cascant, M. J. (2012). Metodología y técnicas cuantitativas de investigación. In Cuadernos docentes en proceso de desarrollo. Valencia: Universidad Politécnica de Valencia.

Lévy, P. (2004). Inteligencia colectiva: por una antropología del ciberespacio. Retrieved from https://goo.gl/qe8MWw

Mañero-Contreras, J. (2016). Estudio de caso de los sMOOC y su pedagogía en el contexto online. Revista Mediterránea de Comunicación, 7(2), 37-46. doi:10.14198/MEDCOM2016.7.2.3

Marta-Lazo, C., Hergueta-Covacho, E., \& Gabelas-Barroso, J. A. (2016). Applying inter-methodological concepts for enhancing media literacy competences. Journal of Universal Computer Science, 22(1), 37-54. Retrieved from https://goo.gl/ DWkj58.

Marta-Lazo, C., Marfil-Carmona, R., \& Hergueta-Covacho, E. (2016). Aplicación de las redes sociales en el aprendizaje en conectividad: Uso del Factor Relacional en la dialéctica Twitter. Etic@.net, 16(1), 304-319. Retrieved from https://goo. gl/hpgyfY

Martínez-Pérez, J. (2016). El empoderamiento del alumnado desde el modelo sMOOC. Revista Mediterránea de Comunicación, 7(2), 69-79. doi:10.14198/MEDCOM2016.7.2.6

Nielsen, J. (2006). The 90-9-1 rule for participation inequality in social media and online communities. Retrieved from https://goo.gl/ze85T6

Osuna-Acedo, S., Frau-Meigs, D., Camarero-Cano, L., Bossu, A., Pedrosa, R., \& Jansen, D. (2017). Intercreativity and interculturality in the virtual learning environments of the ECO MOOC project. In M. Jemni, M. K. Kinshuk, \& Khribi (Eds.), Open education: From OERs to MOOCs. Series lecture notes in educational technology (pp. 161-187). Berlin: Springer. doi:10.1007/978-3-662-52925-6_9

Osuna-Acedo, S., \& Gil-Quintana, J. (2017). El proyecto europeo ECO. Rompiendo barreras en el acceso al conocimiento. [The European project ECO. Breaking down barriers to access knowledge]. Educación XX1, 20(2), 189-213. Retrieved from https://10.5944/educXX1.15852

Osuna-Acedo, S., Marta-Lazo, C., \& Frau-Meigs, D. (2018). From sMOOC to tMOOC, learning towards professional transference. ECO European Project. Revista Comunicar, XXVI(55), 105-114. doi:10.3916/C55-2018-10

Piñuel, J. L. (2002). Epistemología, metodología y técnicas del análisis de contenido. Sociolinguistic Studies, 3(1), 1-42.

Siemens, G. (2004). Connectivism: A learning theory for the digital age. Retrieved from https://goo.gl/fzdXvM

Siemens, G., Downes, S., \& Cormier, D. (2012). How this course works, en: Learning Analytics and Knowledge: LAK12. Retrieved from http://goo.gl/Ee5ali

Sosa, M. J., López, C., \& Díaz, S. R. (2014). Comunidad de aprendizaje y participación social en un curso MOOC. International Journal of Educational Research and Innovation (IJERI), 1, 1-13. Retrieved from https://goo.gl/XQnE8f

Torres Mancera, D., \& Gago Saldaña, D. (2014). Los MOOCs y su papel en la creación de comunidades de aprendizaje y participación. RIED. Revista Iberoamericana de Educación a Distancia, 17(1). doi:10.5944/ried.17.1.11570

Traphagan, T., Traphagan, J., Neavel Dickens, L., \& Resta, P. (2014). Changes in college students' perceptions of use of web-based resources for academic tasks with Wikipedia projects: A preliminary exploration. Interactive Learning Environments, 22(3), 253-270. doi:10.1080/10494820.2011.641685

Vázquez, E., López, E., \& Sarasola, J. L. (2013). La expansión del conocimiento abierto: los MOOC. Barcelona: Octaedro.

Veletsianos, G., Collier, A., \& Schneider, E. (2015). Digging deeper into learners' experiences in MOOCs: Participation in social networks outside of MOOCs, notetaking and contexts surrounding content consumption. British Journal of Educational Technology, 46(3), 570-587. Retrieved from http://10.1111/bjet.12297

Vigotsky, L. S. (1979). El desarrollo de los procesos psicológicos superiores. Madrid: Editorial Grijalbo.

Waite, M., Mackness, J., Roberts, G., \& Lovegrove, E. (2013). Liminal participants and skilled orienteers: Learner participation in a MOOC for new lecturers. MERLOT Journal of Online Learning and Teaching, 9(2), 200-215. Retrieved from https://goo.gl/597WQd

Wenqiang, F. (2012). Connectivist MOOC and its learning support. Journal of Distance Education, 3, 31-36. Retrieved from https://goo.gl/QXbz22

Yousef, A. M. F., Chatti, M. A., Wosnitza, M., \& Schroeder, U. (2015). A cluster analysis of MOOC stakeholder perspectives. RUSC. Universities and Knowledge Society Journal, 12(1), 74-90. doi:10.7238/rusc.v12i1.2253 